\section{PEMBUATAN BATAS}

WILAYAH DI

KELURAHAN

BONTOTANGGA

KEC.TAMALATEA

Oleh:

Nama : Almi aviani sofyan

Nim : 9173490210016

Email : almiavianis.99@gmail.com

\section{Bentuk kegiatan}

Pembuatan

batas

wilayah 2. Lokasi

Posko KKLP di Kelurahan Bonto

Tangnga Kec.Tamalatea

\section{Hari/Tanggal dan Waktu}

Jum'at, 02 Oktober 2020 pukul

$14: 00$

\section{Peserta yang dilibatkan}

Mahasiswa KKLP

5. Alasan diadakannya Setelah observasi lapangan, kami melihat bahwa di beberapa lingkungan terdapat batas wilayah yang perlu di perbaharui .
6. Tujuan dan Manfaat Kami mengadakan program kerja ini agar masyarakat lebih mudah mengetahui batas wilayah di daerah tersebut.

7. Deskripsi kegiatan Proses pembuatan batas wilayah di lakukan selama beberapa hari, pembuatan batas wilayah ini di lakukan sebagai upaya memberikan kemudahan terhadap masyarakat dalam mengenali wilayah atau daerah tersebut. 